\title{
Evaluation of the antibacterial activity of ethanolic extracts obtained from roots and stalks of Chelidonium majus L. against Escherichia coli strains
}

\author{
Nataniel Stefanowski, Halyna Tkachenko*, Natalia Kurhaluk \\ Institute of Biology and Earth Sciences, Pomeranian University in Słupsk, Poland
}

Article Details:

Received: 2021-03-21

Accepted: 2021-04-12

Available online: 2021-05-31

Nowadays, antibiotic resistance among pathogenic bacteria is increasingly common. The Chelidonium majus L. is one of the most widely used genera in folk medicine, where it is popular for its antibacterial activity. The purpose of this study was to evaluate the antimicrobial effects of five ethanolic extracts obtained from stalks and roots of $C$. majus collected from the rural and urban agglomerations on the territory of the Kartuzy district in the Pomeranian province (northern part of Poland) against Escherichia coli strains. The Escherichia coli (Migula) Castellani and Chalmers (ATCC $® 25922^{\mathrm{TM}}$ ) and Escherichia coli Castellani and Chalmers (ATCC ${ }^{2}$ 25922 ${ }^{\mathrm{TM}}$ ) strains were used in the current study. It has been observed that ethanolic extracts derived from stalks and roots of $C$. majus collected from rural and urban areas revealed weak antibacterial activity (7.95-8.25 $\mathrm{mm}$ as the diameters of inhibition zone) compared to the control samples. Our results revealed that the extracts derived from stalks and roots of $C$. majus have shown weak antibacterial activity against the tested strains. The detailed chemistry of the active compounds and possible mechanism(s) of actions of the bio-molecules responsible for the observed activity was not addressed in the current study. Thus, further evaluation for the nature of active compounds (bio-molecules) and detailed mechanism(s) of their interaction with microbial strains are recommended.

Keywords: Chelidonium majus L., Escherichia coli (Migula) Castellani and Chalmers (ATCC@ 25922 ${ }^{\mathrm{TM}}$ ), Escherichia coli (Migula) Castellani and Chalmers (ATCC $® 35218^{\mathrm{TM}}$ ), disc diffusion techniquey

\section{Introduction}

Escherichia coli, a rod-shaped Gram-negative bacteria and a member of the bacterial family of Enterobacteriaceae, is the most prevalent commensal inhabitant of the gastrointestinal tracts of humans and warm-blooded animals, as well as one of the most important pathogens (Kaper, 2005). As a commensal, it lives in a mutually beneficial association with hosts and rarely causes diseases. It is, however, also one of the most common human and animal pathogens as it is responsible for a broad spectrum of diseases such as diarrhea, hemolytic uremic syndrome, and hemorrhagic colitis leading to acute renal failure and often death (Allocati et al., 2013; Jang et al., 2017). E. coli also includes pathogens of global significance that are responsible for epidemic dysentery (e.g. Shigella), neonatal meningitis (associated with the K1 capsular polysaccharide), hemolytic uremic syndrome (0157:H7), as well as a variety of other diseases (Wirt et al., 2006). The prevalence of multidrug-resistant $E$. coli strains is increasing worldwide principally due to the spread of mobile genetic elements, such as plasmids (Allocati et al., 2013). The genetic structure of commensal E. coli is shaped by multiple host and environmental factors. The determinants involved in the virulence of the bacteria may reflect adaptation to commensal habitats (Tenaillon et al., 2010). The increase of multidrug-resistant strains of $E$. coli also occurs in Europe and the spread of resistance in E. coli

\footnotetext{
*Corresponding Author: Halyna Tkachenko, Institute of Biology and Earth Sciences, Pomeranian University in Słupsk, Arciszewski Str. 22b, 76-200 Słupsk, Poland $\triangle$ tkachenko@apsl.edu.pl
} 
is an increasing public health concern in European countries (Allocati et al., 2013).

In the face of the rapidly increasing antibiotic resistance of microorganisms including bacteria, we tried to find alternative solutions to this actual problem. In the common knowledge of an ethnomedicine, it is known that plants contain a wide range of compounds including polyphenols, alkaloids, carotenoids, tannins that exhibit antibacterial properties. One of them is a representative of the Papaveraceae family, the greater celandine (Chelidonium majus L.), which we have taken a detailed interest in.

C. majus is a perennial plant growing in regions of moderate climate, on the continents of Europe, Asia, North America, and a part of Northwest Africa. In Poland, it is found across the entire country (Zielińska et al., 2018). The greater celandine herb is rich in medically valuable natural compounds. Their highest amounts are contained in immature fruits $(2.4 \%)$ and roots ( $4 \%$ ), while the aerial parts of the plant contain around $0.5 \%$ of active compounds. The plant contains, first of all, alkaloids benzylisoquinoline compounds (0.01-1.0\%), such as sanguinarine, chelidonine, chelerythrine, and protoberberines, berberine, coptisine (Táborská et al., 1995; Shafiee and Jafarabadi, 1998; Kopytko etal., 2005; Pan etal., 2017; Warowicka et al., 2019). Crude extracts of several alkaloids extracted from C. majus exhibited antimicrobial, antiviral, and antifungal properties (Nawrot et al., 2020). Other compounds structurally unrelated to the alkaloids have been isolated from the aerial parts: several flavonoids and phenolic acids. C. majus extracts and their purified compounds exhibit interesting antiviral, antitumor, and antimicrobial properties both in vitro and in vivo (Colombo and Bosisio, 1996).

Considering the points highlighted above and based on previous results obtained in our laboratory, the current study aimed to find out in vitro possible antimicrobial activity of the ethanolic extracts derived from roots and stalks of Chelidonium majus against two Escherichia coli strains.

\section{Material and methodology}

\section{Collection of plant material}

Plant materials (Figure 1B) were harvested from natural habitats on the territory of the Kartuzy district $\left(54^{\circ} 20^{\prime} \mathrm{N} 18^{\circ} 12^{\prime} \mathrm{E}\right)$ in the Pomeranian province (northern part of Poland) (Figure 1A). Kartuzy is located about 32 kilometers (20 miles) west of Gdańsk and $35 \mathrm{~km} \mathrm{(22} \mathrm{miles)} \mathrm{South-East} \mathrm{of} \mathrm{the} \mathrm{town}$ of Lębork on a plateau at an altitude of approximately 200 meters (656 feet) above sea level on average. The plateau, which is divided by the Radaune lake, comprises the highest parts of the Baltic Sea Plate (http://www.kartuzy.pl/). Plants were collected from urban $(n=5)$ and rural agglomerations $(n=15)$ on the territory of the Kartuzy district.

\section{Preparation of plant extracts}

The collected roots and stalks were brought into the laboratory for antimicrobial studies. Freshly washed samples were weighed, crushed, and homogenized in $96 \%$ ethanol (in proportion $1: 19, \mathrm{w} / \mathrm{w}$ ) at room temperature. The extracts were then filtered and investigated for their antimicrobial activity.

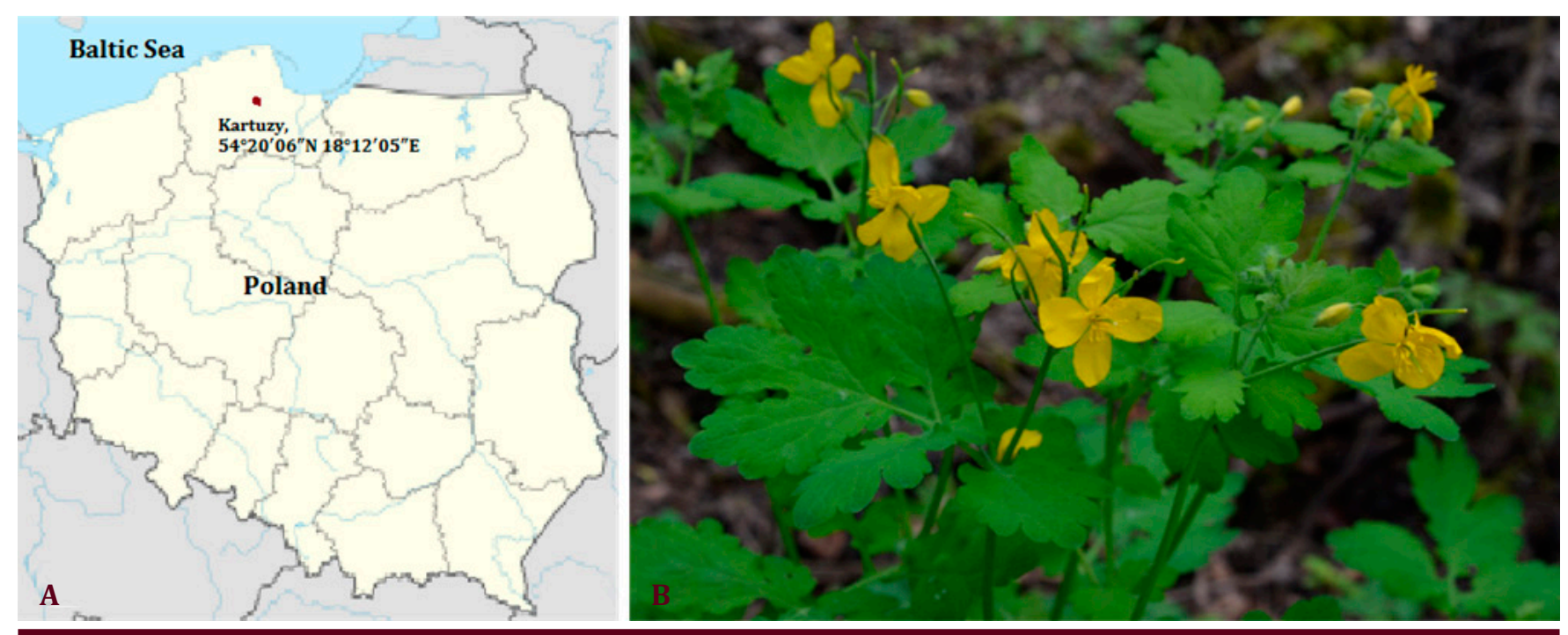

Figure 1 Location of Kartuzy in the map of Poland (A), where the Chelidonium majus L. (B) was collected 


\section{The disk diffusion method for evaluation of antibacterial activity of plant extracts}

The Escherichia coli (Migula) Castellani and Chalmers (ATCC $® 25922^{\text {TM }}$ ) and Escherichia coli (Migula) Castellani and Chalmers (ATCC $® 25922^{\text {TM }}$ ) strains were used in the current study. Strains tested were plated on TSA medium (Tryptone Soy Agar) and incubated for $24 \mathrm{~h}$ at $37^{\circ} \mathrm{C}$. Then the suspension of microorganisms was suspended in sterile PBS and the turbidity adjusted equivalent to that of a $0.5 \mathrm{McF}$ arland standard. The antimicrobial susceptibility testing was done on MullerHinton agar by disc diffusion method (Kirby-Bauer disk diffusion susceptibility test protocol) (Bauer et al., 1966). Muller-Hinton agar plates were inoculated with $200 \mu \mathrm{l}$ of standardized inoculum $\left(10^{8} \mathrm{CFU} / \mathrm{mL}\right)$ of the bacterium and spread with sterile swabs.

Sterile filter paper discs impregnated by extracts were applied over each of the culture plates, 15 min after bacteria suspension was placed. A negative control disc impregnated by sterile $96 \%$ ethanol was used in each experiment. After culturing bacteria on MuellerHinton agar, the disks were placed on the same plates and incubated for $24 \mathrm{hr}$ at $37{ }^{\circ} \mathrm{C}$. The assessment of antimicrobial activity was based on the measurement of the diameter of the inhibition zone formed around the disks. The diameters of the inhibition zones were measured in millimeters and compared with those of the control and standard susceptibility disks. The activity was evidenced by the presence of a zone of inhibition surrounding the well (CLSI, 2014). The results of the disk diffusion test are "qualitative," in that a category of susceptibility (i.e., susceptible, intermediate, or resistant) is derived from the test rather than a MIC (Jorgensen and Ferraro, 2009).

\section{Statistical analysis}

Zone diameters were determined and averaged. Statistical analysis of the data obtained was performed by employing the mean. All variables were randomized according to the antibacterial activity of tested extracts. All statistical calculation was performed on separate data from each extract. The data were analyzed using one-way analysis of variance (ANOVA) using Statistica software, version 8.0 (StatSoft, Poland) (Zar, 1999). The following zone diameter criteria were used to assign susceptibility or resistance of bacteria to the phytochemicals tested: Susceptible (S) $\geq 15 \mathrm{~mm}$, Intermediate $(\mathrm{I})=10-15 \mathrm{~mm}$, and Resistant (R) $\leq 10 \mathrm{~mm}$ (Okoth et al., 2013).

\section{Results and discussion}

Our study aimed to examine the antibacterial properties of $C$. majus roots and stalks against two Escherichia coli strains. The extracts derived from stalks and roots of $C$. majus collected from the rural and urban agglomerations have shown weak antibacterial activity against the tested strains. The results of antibacterial activity screening are given in Figure $2-5$, which indicate that the extracts have shown weak antibacterial activity against the two E. coli strains. The data on diameters of zone inhibition of bacterial growth of plant extracts against the Escherichia coli (Migula) Castellani and Chalmers (ATCC $® 25922^{\mathrm{TM}}$ ) strain is demonstrated in Figure 2 and 3.

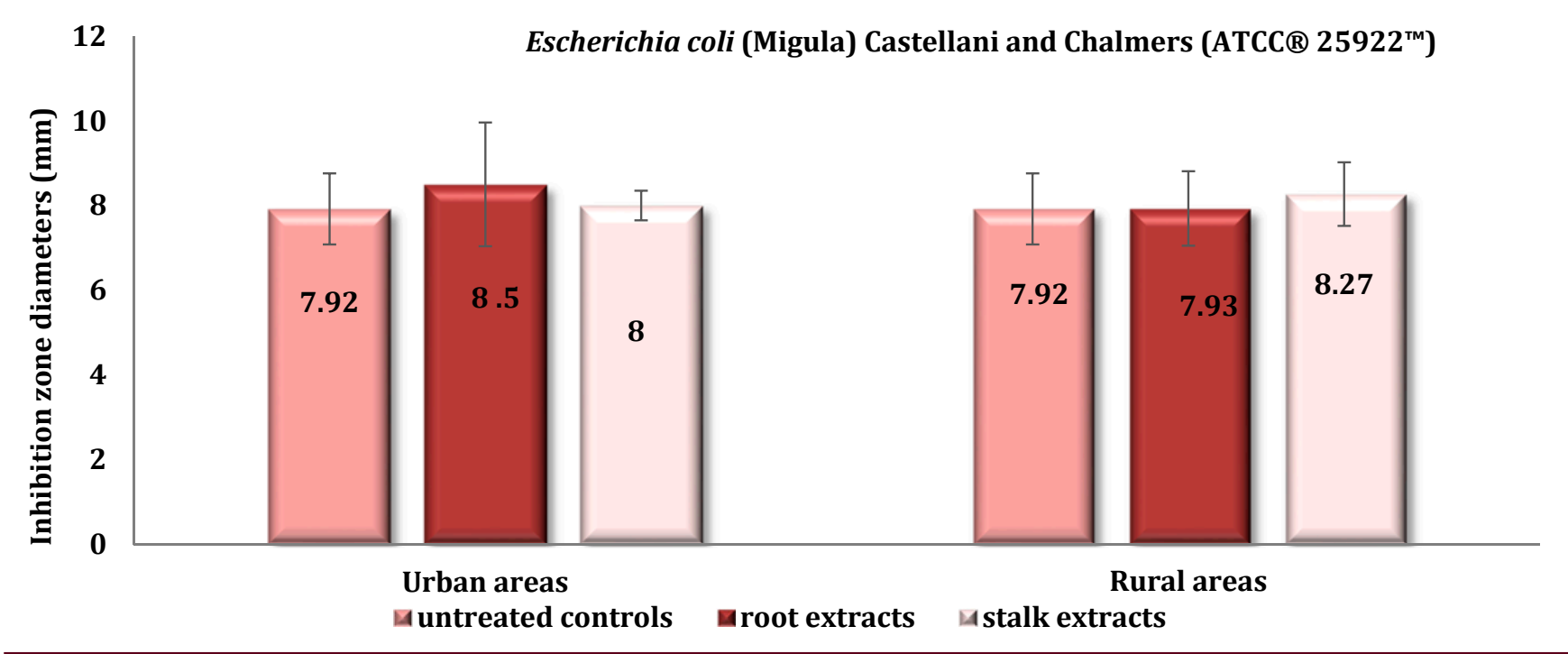

Figure 2 Zones of growth inhibitions of Escherichia coli (Migula) Castellani and Chalmers (ATCC® 25922 ${ }^{\mathrm{TM}}$ ) strain induced by the extracts obtained from stalks and roots of Chelidonium majus L. collected from the rural and urban agglomerations in millimeter $(\mathrm{M} \pm \mathrm{m}, \mathrm{n}=8)$ 


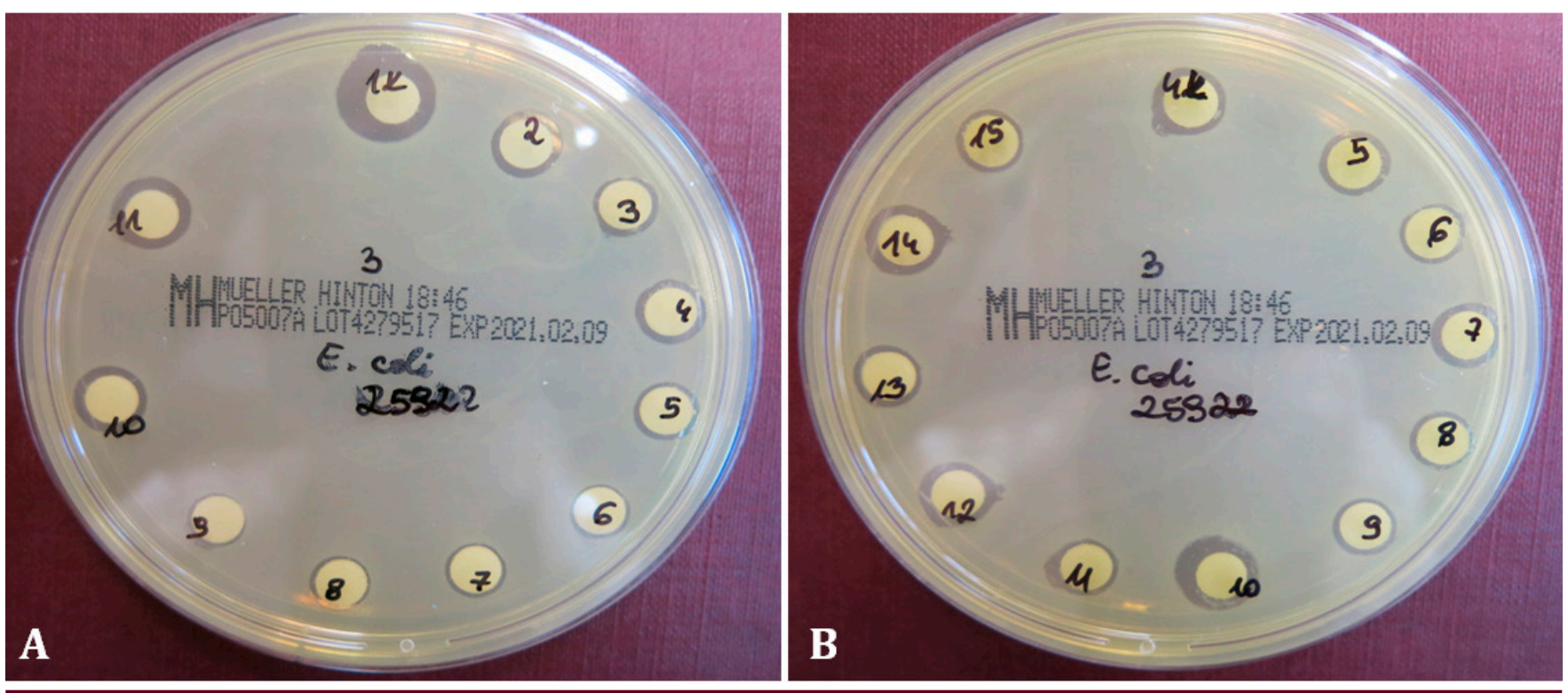

Figure 3 Example of plates in a disc diffusion assay showing the halos in the bacterial growth resulting from the antibacterial activity of extracts derived from roots (A) and stalks of Chelidonium majus L. (B) collected from the rural and urban agglomerations against Escherichia coli (Migula) Castellani and Chalmers (ATCC $\left(25922^{\mathrm{TM}}\right.$ ) strain

The extracts derived from roots collected in urban agglomeration have shown more considerable activity against the Escherichia coli (Migula) Castellani and Chalmers (ATCC $® 25922^{\mathrm{TM}}$ ) strain. The mean diameters of inhibition zones were $(8.5 \pm 0.65) \mathrm{mm}$ compared to the control sample $(8.1 \pm 0.75) \mathrm{mm}$. Similar results were obtained from the extracts derived from stalks of C. majus collected in rural agglomerations, i.e. (8.27 \pm 0.19$) \mathrm{mm}$ compared to the control samples $(7.92 \pm 0.84)$. The stalk extracts have exhibited fewer antimicrobial activities against $E$. coli. The mean of the inhibition zone diameters was $(8.0 \pm 0.16) \mathrm{mm}$. Finally, the ethanolic extracts derived from roots of $C$. majus collected from rural agglomerations exhibited weak antibacterial activity against $E$. coli (mean of inhibition zone ranged $7.93 \pm 0.23 \mathrm{~mm}$ ).

The present study has shown that ethanolic extracts derived from the roots of C. majus from urban agglomerations also exhibited weak antibacterial activity against Escherichia coli (inhibition zone diameter was ranged from 7.95 to $8.5 \mathrm{~mm}$ ) (Figure 4). Moreover, it has been observed that ethanolic extracts derived from stalks of $C$. majus collected from rural areas also revealed similar antibacterial activity

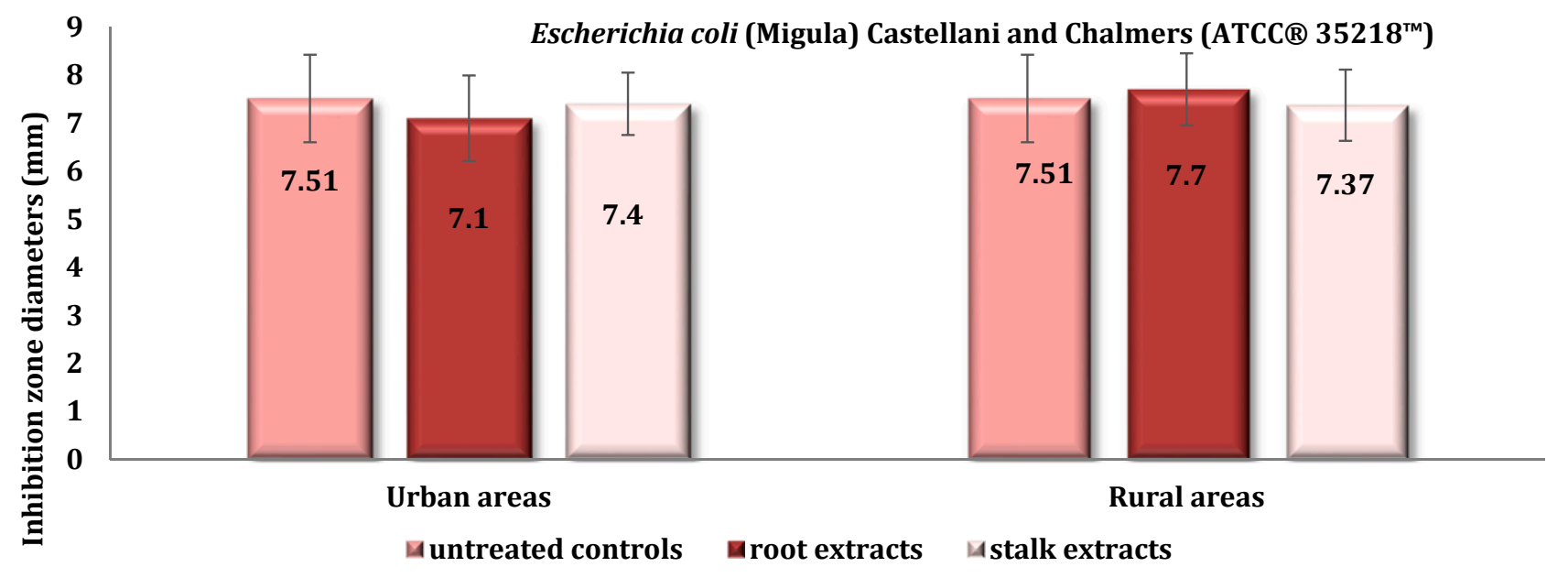

Figure 4

Zones of growth inhibitions of Escherichia coli (Migula) Castellani and Chalmers (ATCC® $35218^{\mathrm{TM}}$ ) strain induced by the extracts obtained from stalks and roots of Chelidonium majus L. collected from the rural and urban agglomerations in millimeter $(\mathrm{M} \pm \mathrm{m}, \mathrm{n}=8)$ 


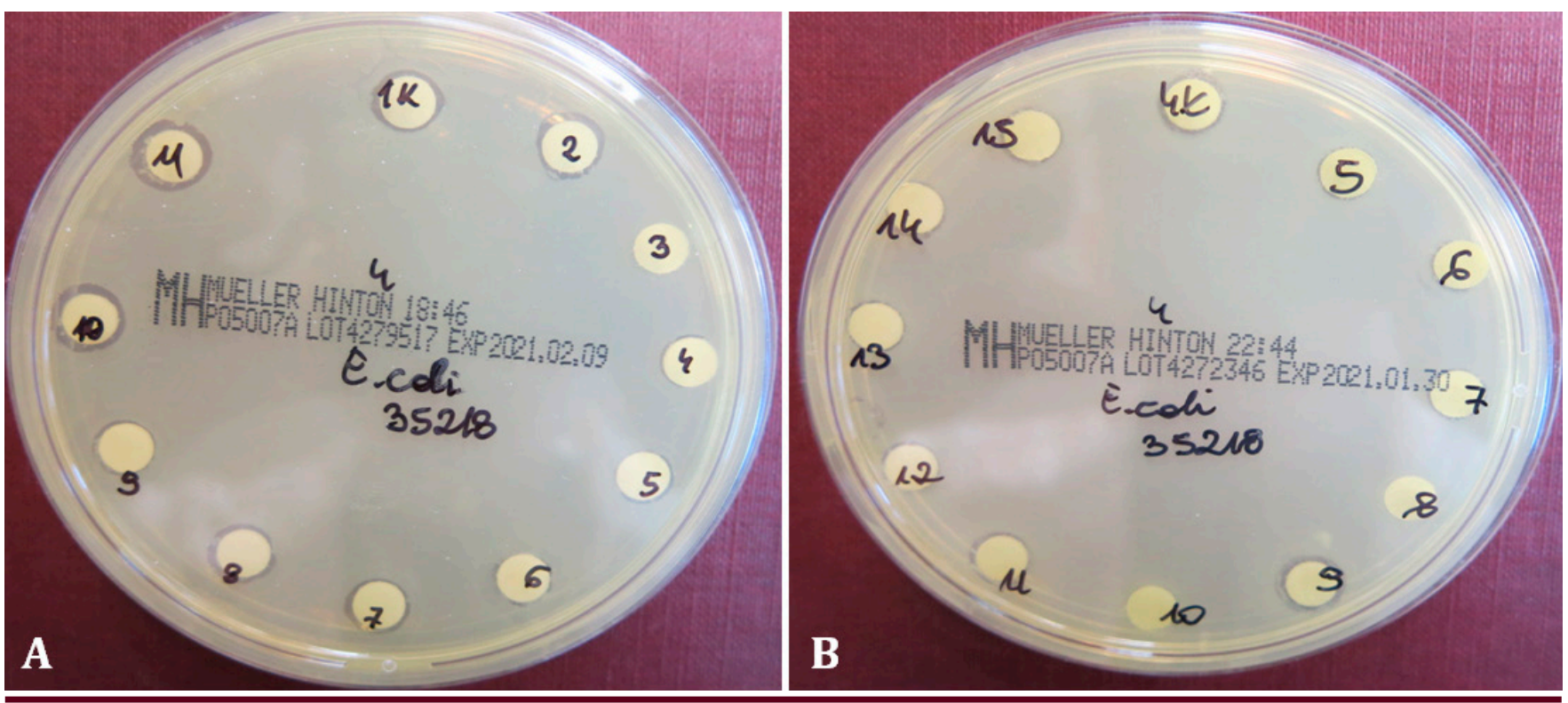

Figure 5 Example of plates in a disc diffusion assay showing the halos in the bacterial growth resulting from the antibacterial activity of extracts derived from roots (A) and stalks of Chelidonium majus L. (B) collected from the rural and urban agglomerations against Escherichia coli (Migula) Castellani and Chalmers (ATCC® $35218^{\mathrm{TM}}$ ) strain

(7.95-8.25 $\mathrm{mm}$ as the diameters of inhibition zone) compared to the control samples (Figures 4 and 5).

The extracts derived from roots collected in rural agglomeration have shown weak activity against the E. coli strain (Figure 5). The mean diameters of inhibition zones were $7.7 \pm 0.65 \mathrm{~mm}$ compared to the control sample $7.51 \pm 0.75 \mathrm{~mm}$. The extracts taken from the urban agglomeration showed no significant changes compared to the control sample. The above results show that only root extracts collected from rural areas can have weak antibacterial properties against this strain (Figure 5).

In this study, we investigated the antimicrobial activity of plant extracts by agar disc diffusion assay. In the current study, extracts derived from roots and stalks of $C$. majus collected from the rural and urban agglomerations were less potent against the test bacterium due to the observed zone of growth inhibitions.

Our results are not similar in comparison to another. C. majus is listed among one of the most active antimicrobial plants in a screening study by Kokoska et al. (2002). Crude extracts and several alkaloids isolated from C. majus exhibited antibacterial, antiviral, and antifungal properties. In experiments with multidrugresistant bacteria existing in surgical wounds and infections of critically ill patients, C. majus ethanol extract affected Gram-positive bacteria. Ethanolic extracts of $C$. majus also showed antimicrobial activity against Bacillus cereus, E. coli, Pseudomonas aeruginosa,
S. aureus (Kokoska et al., 2002). Zielińska et al. (2019) have evaluated the antimicrobial activity of seven alkaloids and C. majus extracts from plants derived from natural habitats and in vitro cultures. A comparison of the alkaloid profile of extracts obtained from aerial parts and roots of plants collected from different habitats was also performed using chromatographic techniques. Moreover, the antimicrobial activity of seven major alkaloids was tested and the results were correlated with alkaloid content. All tested plant extracts manifested antimicrobial activity, related to different chemical structures of the alkaloids. Root extract used at 31.25-62.5 mg/L strongly reduced bacterial biomass. From the seven individually tested alkaloids, chelerythrine was the most effective against Pseudomonas aeruginosa (MIC at $1.9 \mathrm{mg} / \mathrm{L}$ ), while sanguinarine against $S$. aureus (MIC at $1.9 \mathrm{mg} / \mathrm{L}$ ). Strong antifungal activity was observed against C. albicans when chelerythrine, chelidonine, and aerial parts extract were used (Zielińska et al., 2019). The antibacterial effect of extracts and compounds isolated from the aerial part of $C$. majus acting against clinical strains of methicillin-resistant Staphylococcus aureus (MRSA) was evaluated in the study of Zuo et al. (2008). The selective antibacterial activity against MRSA for 8-hydroxylated benzo[c]phenanthridine-type alkaloids isolated from C. majus was revealed.

The complex composition of alkaloids can manifest a wide spectrum of antimicrobial activity, arising from different chemical structures of the compounds. 
Hence, the antimicrobial activity of $C$. majus was also tested with use of various solvent extraction by Cirić et al. (2008). Antibacterial and antifungal tests were performed using $96 \%$ methanol extracts from leaves and petioles of plants grown in nature as well as in vitro shoots and embryos (Cirić et al., 2008). The following Gram-positive bacteria were used: Bacillus subtilis ATCC 10707, Micrococcus luteus ATCC 9341, Sarcinia lutea ATCC 9391, and Staphylococcus aureus ATCC 6538, in addition to the Gram-negative bacteria Agrobacterium rhizogenes A4M70GUS, A. tumefacians A281, Escherichia coli ATCC 35218, Proteus mirabilis (clinical isolates), and Salmonella enteritidis ATCC 13076; and the yeast Candida albicans (clinical isolates). Methanol extracts of all samples showed significant activity against Gram-positive and Gramnegative bacteria and $C$. albicans. The extracts were not effective only against $P$. mirabilis. Extracts from various explants had higher antimicrobial activity against the tested microorganisms than that recorded for extracts from leaves and petioles of plants growing outdoors. When the results were compared with the antimicrobial activities of positive controls (streptomycin or bifonazole), some extracts showed equal antimicrobial activity against $E$. coli, S. enteritidis, and C. albicans (Cirić et al., 2008).

Singly from plant extracts, as it was previously summarized by Kędzia et al. (2013), Kędzia and Hołderna-Kedzia (2013), individually tested compounds showed different antimicrobial activity. Chelerythrine and sanguinarine were significantly more potent than chelidonine against Gram-positive (Staphylococcus aureus, S. epidermidis, B. subtilis, B. anthracis), Gram-negative (Pseudomonas aeruginosa, E. coli, Klebsiella pneumoniae, Salmonella gallinarum, S. typhi, S. paratyphi, Proteus vulgaris, Shigella flexneri) and acid-fast mycobacteria (Mycobacterium tuberculosis, M. smegmatis). Pan et al. (2017) have investigated an efficient method to purify chelidonine from the extract of $C$. majus using macroporous adsorption resins and evaluated the antifungal activity of chelidonine against Botryosphaeria dothidea as a model strain. The antifungal activity of enriched chelidonine products was studied with $B$. dothidea. The results showed that the $\mathrm{EC}_{50}$ of crude extracts, enriched chelidonine products, and the chelidonine standard against $B$. dothidea was $3.24 \mathrm{mg} / \mathrm{mL}, 0.43 \mathrm{mg} / \mathrm{mL}$, and $0.7 \mathrm{mg} / \mathrm{mL}$, respectively. The result of the antifungal activity test showed that chelidonine had the potential to be a useful antifungal agent (Pan et al., 2017).

According to Migas and Heyka (2011), an effective and safe to use antimicrobial compound is berberine. This is supported by studies on adult patients with acute diarrhea caused by enterotoxin Escherichia coli and Vibrio cholerae. Berberine reduces the hypersecretion of water and electrolytes induced by cholera toxin, as well as shortens the passage time of gastrointestinal contents through the small intestine. The in vitro studies of Migas and Heyka (2011) have shown that berberine sulfate inhibits $E$. coli cell adhesion to the mucosal epithelium, which may be related to blocking and preventing the formation of fimbriae on the bacterial cell surface. Enzymes synthesized by buttercup also exhibit antimicrobial activity. The plant synthesizes biologically active proteins: glycoproteins with lectin and DNA-ase activity, as well as two extracellular peroxidases (isolated from milk sap latex), which participate in the formation of hydrogen peroxide and other reactive oxygen species, protecting the plant from pathogenic microorganisms.

\section{Conclusions}

The ethanolic extracts of Chelidonium majus revealed weak antibacterial activity against both Escherichia coli (Migula) Castellani and Chalmers (ATCC ${ }^{\circ} 25922^{\mathrm{TM}}$ ) and E. coli (Migula) Castellani and Chalmers (ATCC $®$ $35218^{\mathrm{TM}}$ ) strains. The findings reported herein suggest that extracts derived from the different parts of $C$. majus merit further microbiological and chemical study as natural antibiotics to the assessment of antibacterial activity and identify secondary metabolites. The present study lays the basis for future research, to validate the possible use of $C$. majus as a candidate in the treatment of bacterial infections. The knowledge about the chemical profile of the extract will help in explaining the observed activity and designing experiments for activity fractionation for isolation of the active principle. The identification of precise molecular mechanisms addressing how these extracts inhibit bacterial growth needs to be explored.

\section{Acknowledgments}

This study was funded by Pomeranian University in Słupsk. We thank Prof. Danuta Gierczyńska for financially supporting our study.

\section{References}

ALLOCATI, N., MASUlli, M., ALEXEYEV, M.F., DI ILIO, C. 2013. Escherichia coli in Europe: an overview. In Int. J. Environ. Res. Public Health, vol. 10(12), p. 6235-6254. https://doi.org/10.3390/ijerph10126235

BAUER, A.W., KIRBY, W.M., SHERRIS, J.C., TURCK, M. 1966. Antibiotic susceptibility testing by a standardized single disk method. In Am. J. Clin. Pathol., vol. 45(4), p. 493-496. 
ĆIRIĆ, A., VINTERHALTER, B., ŠAVIKIN-FODULOVIĆ, K., SOKOVIĆ, M., VINTERHALTER, D. 2008. Chemical analysis and antimicrobial activity of methanol extracts of celandine (Chelidonium majus L.) plants growing in nature and cultured in vitro. In Arch. Biol. Sci. Belgrade, vol. 60(1), p. 7P-8P.

https://doi.org/10.2298/ABS080107PC

CLSI. 2014. Performance Standards for Antimicrobial Susceptibility Testing. Clinical and Laboratory Standards Institute; Wayne, PA, USA: 2014. CLSI M100-S24.

COLOMBO, M.L., BOSISIO, E. 1996. Pharmacological activities of Chelidonium majus L. (Papaveraceae). In Pharmacol. Res., vol. 33(2), p. 127-134.

https://doi.org/10.1006/phrs.1996.0019

JANG, J., HUR, H.G., SADOWSKY, M.J., BYAPPANAHALLI, M.N., YAN, T., ISHII, S. 2017. Environmental Escherichia coli: ecology and public health implications - a review. In J. Appl. Microbiol., vol. 123(3), p. 570-581. https://doi.org/10.1111/jam.13468

JORGENSEN, J.H., FERRARO, M.J. 2009. Antimicrobial susceptibility testing: a review of general principles and contemporary practices. In Clin. Infect. Dis., vol. 49(11), p. 1749-1755. https://doi.org/10.1086/647952

KAPER, J.B. 2005. Pathogenic Escherichia coli. In Int. J. Med. Microbiol., vol. 295(6-7), p. 355-356. https://doi.org/10.1016/j.ijmm.2005.06.008

KĘDZIA, B., HOŁDERNA-KĘDZIA, E. 2013. The effect of alkaloids and other groups of plant compounds on bacteria and fungi. In Postępy Fitoterapii, vol. 1, p. 8-16.

KĘDZIA, B., HOŁDERNA-KĘDZIA, E., GOŹDZICKA-JÓZEFIAK, A., BUCHWALD, W. 2013. The antimicrobial activity of Chelidonium majus L. In Postępy Fitoterapii, vol. 4, p. 236-243.

KOKOSKA, L., POLESNY, Z., RADA, V., NEPOVIM, A., VANEK, T. 2002. Screening of some Siberian medicinal plants for antimicrobial activity. In J. Ethnopharmacol., vol. 82(1), p. 51-53.

https://doi.org/10.1016/s0378-8741(02)00143-5

KOPYTKO, Y.F., DARGAEVA, T.D., SOKOLSKAYA, T.A., GRODNITSKAYA, E.I., KOPNIN, A.A. 2005. New methods for the quality control of a homeopathic matrix tincture of greater celandine. In Pharm. Chem. J., vol. 39, p. 603609. https://doi.org/10.1007/s11094-006-0028-4

MIGAS, P., HEYKA, M. 2011. Greater celandine (Chelidonium majus L.) in modern therapy - indications and safety of use. In Postępy Fitoterapii, vol. 3, p. 208-218.

NAWROT, R., JÓZEFIAK, D., SIP, A., KUŹMA, D., MUSIDLAK, O., GOŹDZICKA-JÓZEFIAK, A. 2017. Isolation and characterization of a non-specific lipid transfer protein from Chelidonium majus L. latex. In Int. J. Biol. Macromol., vol. 104(Pt A), p. 554-563.

https://doi.org/10.1016/i.ijbiomac.2017.06.057

OKOTH, D.A., CHENIA, H.Y., KOORBANALLY, N.A. 2013. Antibacterial and antioxidant activities of flavonoids from Lannea alata (Engl.) Engl. (Anacardiaceae). In Phytochem. Lett., vol. 6, p. 476-481. https://doi.org/10.1016/j.phytol.2013.06.003
PAN, J., YANG, Y., ZHANG, R., YAO, H., GE, K., ZHANG, M., MA, L. 2017. Enrichment of chelidonine from Chelidonium majus L. using macroporous resin and its antifungal activity. In J. Chromatogr. B Analyt. Technol. Biomed. Life Sci., vol. 1070, p. 7-14. https://doi.org/10.1016/j.jchromb.2017.10.029

SHAFIEE, A., JAFARABADI, A.H. 1998. Corydine and norcorydine from the roots of Chelidonium majus. In Planta Med., vol. 64(5), p. 489. https://doi.org/10.1055/s-2006-957498

TÁBORSKÁ, E., BOCHORÁKOVÁ, H., DOSTÁL, J., PAULOVÁ, H. 1995. Vlastovicník větsí (Chelidonium majus L.) prehled soucasnĕho stavu poznatků [The greater celandine (Chelidonium majus L.) - review of present knowledge]. In Ceska Slov. Farm., vol. 44(2), p. 71-75. [In Czech].

TENAILLON, O., SKURNIK, D., PICARD, B., DENAMUR, E. 2010. The population genetics of commensal Escherichia coli. In Nat. Rev. Microbiol., vol. 8(3), p. 207-217. https://doi.org/10.1038/nrmicro2298

WAROWICKA, A., POPENDA, Ł., BARTKOWIAK, G., MUSIDLAK, O., LITOWCZENKO-CYBULSKA, J., KUŹMA, D., NAWROT, R., JURGA, S., GOŹDZICKA-JÓZEFIAK, A. 2019. Protoberberine compounds extracted from Chelidonium majus L. as novel natural photosensitizers for cancer therapy. In Phytomedicine, vol. 64, p. 152919. https://doi.org/10.1016/j.phymed.2019.152919

WIRTH, T., FALUSH, D., LAN, R., COLLES, F., MENSA, P., WIELER, L.H., KARCH, H., REEVES, P.R., MAIDEN, M.C., OCHMAN, H., ACHTMAN, M. 2006. Sex and virulence in Escherichia coli: an evolutionary perspective. In Mol. Microbiol., vol. 60(5), p. 1136-1151. https://doi.org/10.1111/j.1365-2958.2006.05172.x

ZAR, J.H. 1999. Biostatistical Analysis. $4^{\text {th }}$ ed., Prentice-Hall Inc., Englewood Cliffs, New Jersey.

ZIELIŃSKA, S., JEZIERSKA-DOMARADZKA, A., WÓJCIAKKOSIOR, M., SOWA, I., JUNKA, A., MATKOWSKI, A.M. 2018. Greater celandine's ups and downs-21 centuries of medicinal uses of Chelidonium majus from the view point of today's pharmacology. In Front. Pharmacol., vol. 9, p. 299. https://doi.org/10.3389/fphar.2018.00299

ZIELIŃSKA, S., WÓJCIAK-KOSIOR, M., DZIĄGWA-BECKER, M., GLEŃSK, M., SOWA, I., FIJAŁKOWSKI, K., RURAŃSKASMUTNICKA, D., MATKOWSKI, A., JUNKA, A. 2019. The activity of isoquinoline alkaloids and extracts from Chelidonium majus against pathogenic bacteria and Candida sp. In Toxins (Basel), vol. 11(7), p. 406. https://doi.org/10.3390/toxins11070406

ZUO, G.Y., MENG, F.Y., HAO, X.Y., ZHANG, Y.L., WANG, G.C., XU, G.L. 2008. Antibacterial alkaloids from Chelidonium majus Linn (Papaveraceae) against clinical isolates of methicillin-resistant Staphylococcus aureus. In J. Pharm. Pharm. Sci., vol. 11(4), p. 90-94. https://doi.org/10.18433/j3d30q 